\title{
A Tribute to Thomas Henry Manning 1911-1998
}

\author{
BRENDA CARTER \\ R.R. \#4. Merrickville, Ontario K0G 1N0 Canada
}

Carter, Brenda. 2004. A tribute to Thomas Henry Manning 1911-1998. Canadian Field-Naturalist 118(4): 618-625.

I first met Tom Manning on his Merrickville farm in the spring of 1965, during lambing time. Andrew and Betty Macpherson who had both travelled with him in the Arctic, brought me out to see Arctic Foxes. These captive animals were part of a research program on the influence of light on moult timing. On the way to. Merrickville, I listened to their stories about Tom's legendary explorations and scientific expeditions. I was therefore prepared for the prospect of meeting an Arctic hero. Instead, I found a quiet, stocky man in his fifties, dressed in faded and ragged overalls tending his sheep. The stub of a hand-rolled cigarette hung from his lower lip - perpetually unlit. He did not seem pleased at extra company and bluntly asked why I had been brought out. Later, over glasses of his lethal homemade cider, I realized that here was a man who was much more than he seemed. By the end of that day we had become firm friends $-\mathrm{a}$ friendship that was to last until his death in November of 1998.

Few knew Tom Manning well; and few indeed were given a chance to comprehend, as a whole, the complexity and sheer bulk of his phenomenal life's work. Except for a very few close friends, Tom was deeply private, and even withdrawn. He was a relentless and dogged scientist who spared no effort to find either the original source of any information, or to redo any questionable measurements - even if they were his own. Applying his logical and inquiring mind to all kinds of life-forms, natural phenomena and expedition challenges, Tom also had the skill, intuition and knowledge to assess and react appropriately in critical situations. He did so with a rapidity I found astonishing. His mental brilliance, awesome physical endurance, good looks and charm, combined with great modesty and fondness for red sportscars, contributed to a remarkable personality.

On the 22 of December, 1911, Thomas Henry Manning was born into a gentleman's life. Even as an infant, he defied prediction and showed his amazing capacity for endurance. Except for a surgeon who "did not want to commit murder on Christmas Day" and reluctantly operated, Tom might soon have died, a victim of pyloric stenosis. Tom was the only child of Dorothy (nee Randall) whose brother was the last gentleman jockey in England, and Thomas Edward Manning, (TEM) who managed the family brewery and was cricket Captain for Northamptonshire. Their privileged son was neither destined nor inclined to follow in his father's footsteps.

Tom once told me that his first childhood memory was of being put out on a blanket in the sun before he could walk. He remembered his excitement and freedom at being outside. Tom never lost his passion for open air which propelled him into a life of exploration and adventure. His scientific career began and ended with eggs. As a boy, he had a passion for collecting eggs, and this hobby directed him into a career as a biologist, rather than a brewery owner as his father expected. A friendly gardener sparked his interest in nests, and Tom undoubtedly learned to keep notes and data for his trophies. This mixture of intense interest and attention to detail stood him in good stead as he completed, at the age of seventy, his last pioneering scientific work on weight lost by eggs during incubation for the Canadian Field-Naturalist.

Tom was educated at Harrow, and like his father, attended shooting parties and rode with the famous Pytchley Hunt. There were, however, some interesting dissimilarities. He cleaned the skulls of the mammals and birds shot, drying them in his mother's linen cupboard. Eventually, he escaped from the hunt meets because he disliked the formalities and confining clothes.

While at Harrow, Tom took a cycling trip with a school friend and discovered an unsuspected physical trait. As the pair wound their way through country lanes toward the southern coast of England, he found himself farther and farther ahead. With characteristic independence and detachment from social niceties, he left his friend far behind and continued on, solely interested in how far he could travel in one day. At the end of that journey, he was surprised by his endurance. Although he would never admit it, this ability was more than unusual.

After his death, I discovered a buried manuscript, transcribed from a 1931 diary. It gives an account of his first expedition to Iceland and the Faroe Islands with Harrow school friend, "Twitch" Mitchell. Tom's descriptions of unidentified gulls and seabirds revealed how scrupulous his note-taking was at the young age of twenty. Equally remarkable, for a twenty-year old, was the care he took in logistical planning; from deciding on exact food supplies and arranging trans- 


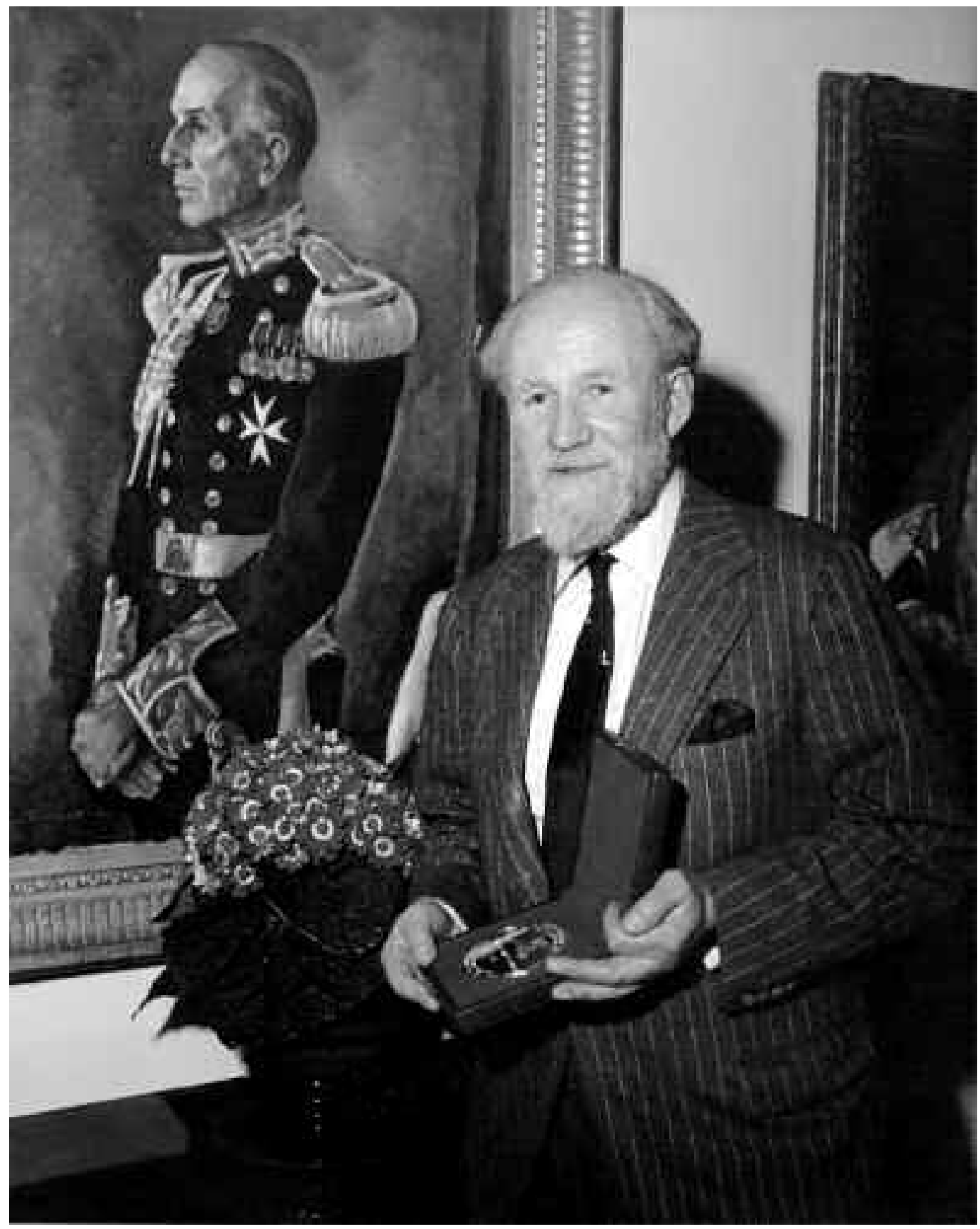

Thomas Henry Manning with Massey Medal presented by the Royal Canadian Geographical Society in 1977 with portrait of former Government-General Vincent Massey in background.

portation, to sorting out necessary visas. This thoroughness remained as long as I knew him. Having travelled with him, I could also recognize in that early diary his trademark dry and ironic humour, hidden in pithy comments about the unfortunate "Twitch", disgruntled bureaucrats and miserable weather.

After Harrow, Tom read Natural Sciences at Jesus College, Cambridge. This academic subject captivat- 
ed him and provided a continuum with his childhood interest in natural history. Owing to several circumstances, the most prominent being boredom, he never took his degree. Instead, in the summer of 1932, at the age of twenty-one, he embarked on a serious journey, walking the length of the Atlantic coast of Norway on his own. Joined later by Reynold Bray, his close school friend from Harrow, the pair proceeded eastward into Finland, making a winter trip by reindeer sledge through Lapland. In 1932, near the end of their trip, they trespassed into Russia. Tom told me they were arrested by villagers armed with pitchforks, who suspected them of spying. They subsequently spent three weeks in a Leningrad jail, being fed on increasingly weakened soup, until the British Consul secured their release.

Exploration, travel and adventure were now Tom's calling. From 1933-1935, he made a solitary expedition to Southampton Island, northern Hudson Bay, to study a Snow Goose colony. He mapped the island under the auspices of the Royal Geographical Society and collected birds and mammals for the British Museum (Natural History). His longest journeys were made by dogsled in winter. From the Inuit of Coral Harbor (on the island's southern coast) he learned how to build an igloo, drive a dog team and hunt seal and caribou. When I once asked why he had an aversion to dumplings, he replied that during that first summer he had been given flour and baking powder by the Hudson's Bay Company Manager. Given no instructions and being too proud to ask what he should make, he existed on a tiresome diet of dumplings until rescued by the Inuit who showed him how to make bannock.

Tom had no sooner returned to England in 1935 than he started to organize a larger expedition to Southampton Island, and Foxe Basin. The five members of the British-Canadian Arctic Expedition, consisting of Tom, Graham Rowley, Reynold Bray, Pat Baird, Richard (Dick) Keeling and Peter Bennett (who later replaced Dick); arrived in Churchill in May of 1936. A smaller team consisting of Tom, Graham and Pat sailing in the Polecat, a 30-foot open whaleboat, established their main base at Coral Harbor. Each pursued his own investigation in biology, archaeology and geology. The expedition was later marred by the tragic death of Reynold Bray, who drowned after being blown out to sea in a collapsible boat.

By the summer of 1938, Tom was alone in the field, at a camp in the Cape Dorset area of southern Baffin Island. He sent a message by Inuit dog team and radio to Montreal to Miss Ella Wallace Jackson (Jackie), a nurse from Nova Scotia whom he had met on the ship that took him back to England in 1935. He invited her to join him in the north. Jackie accepted, and the day after she arrived they were married, using a ring made from a brass fitting by the ship's engineer. A few days later they headed north in a whaleboat. For the next eighteen months they conducted mapping and zoolog-

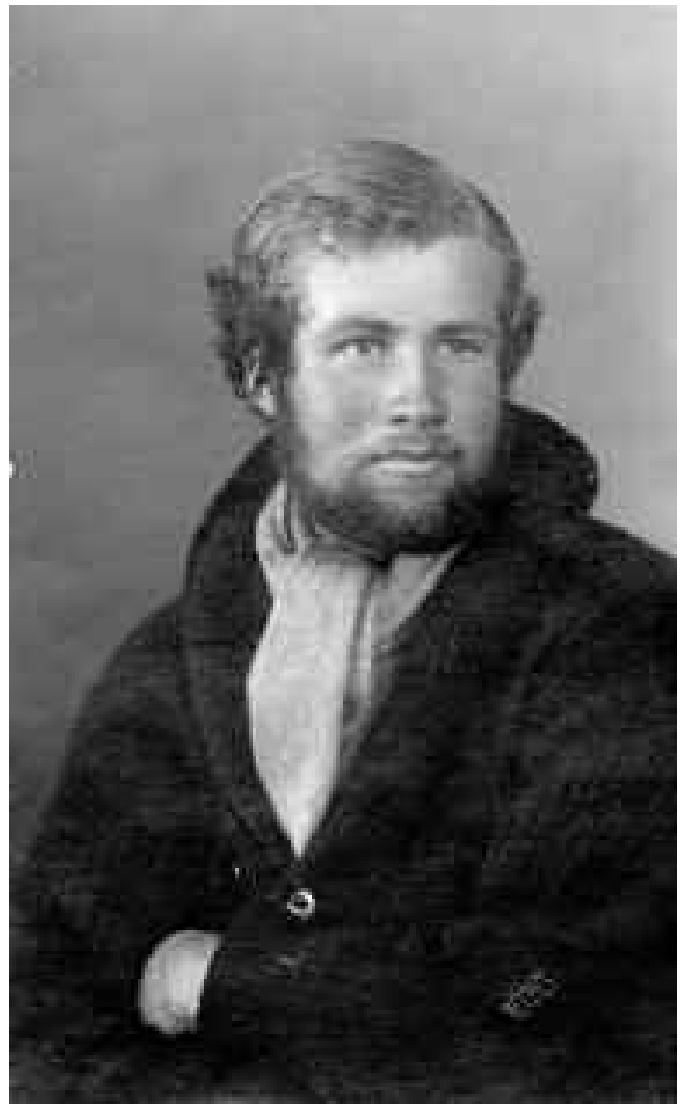

Tom Manning photograph by Borg Mesch, Kiruna, northern Sweden, 1932.

ical studies on the west coast of Baffin Island. Jackie later published two books, Igloo for the Night, The University of Toronto Press, 1946 and A Summer on Hudson Bay, Hodder and Stoughton Ltd., 1949 about their travels together. Although Jackie and Tom spent many years together, the couple separated in the 1960s. Tom often visited her in Ottawa where she still resides.

Late in 1939, Tom had a dream that caused him to head south; he and Jackie arrived in Cape Dorset on 2 January 1940 to learn that World War II had been raging for four months. Anxious to join the war effort, they discovered that the annual resupply ship - due in August - could not get them to Montreal before October. Tom decided they would make their own way back, continuing around the Foxe Basin coast of Baffin Island, hoping to reach Churchill by August. It was 20 January 1941, however, before they reached Churchill, after an epic journey of nearly 2500 miles by boat and dog team, mapping as they went.

Tom received a commission in the Royal Canadian Navy Voluntary Reserve, but was soon seconded to the U.S. Army Engineers to provide advice on the sit- 


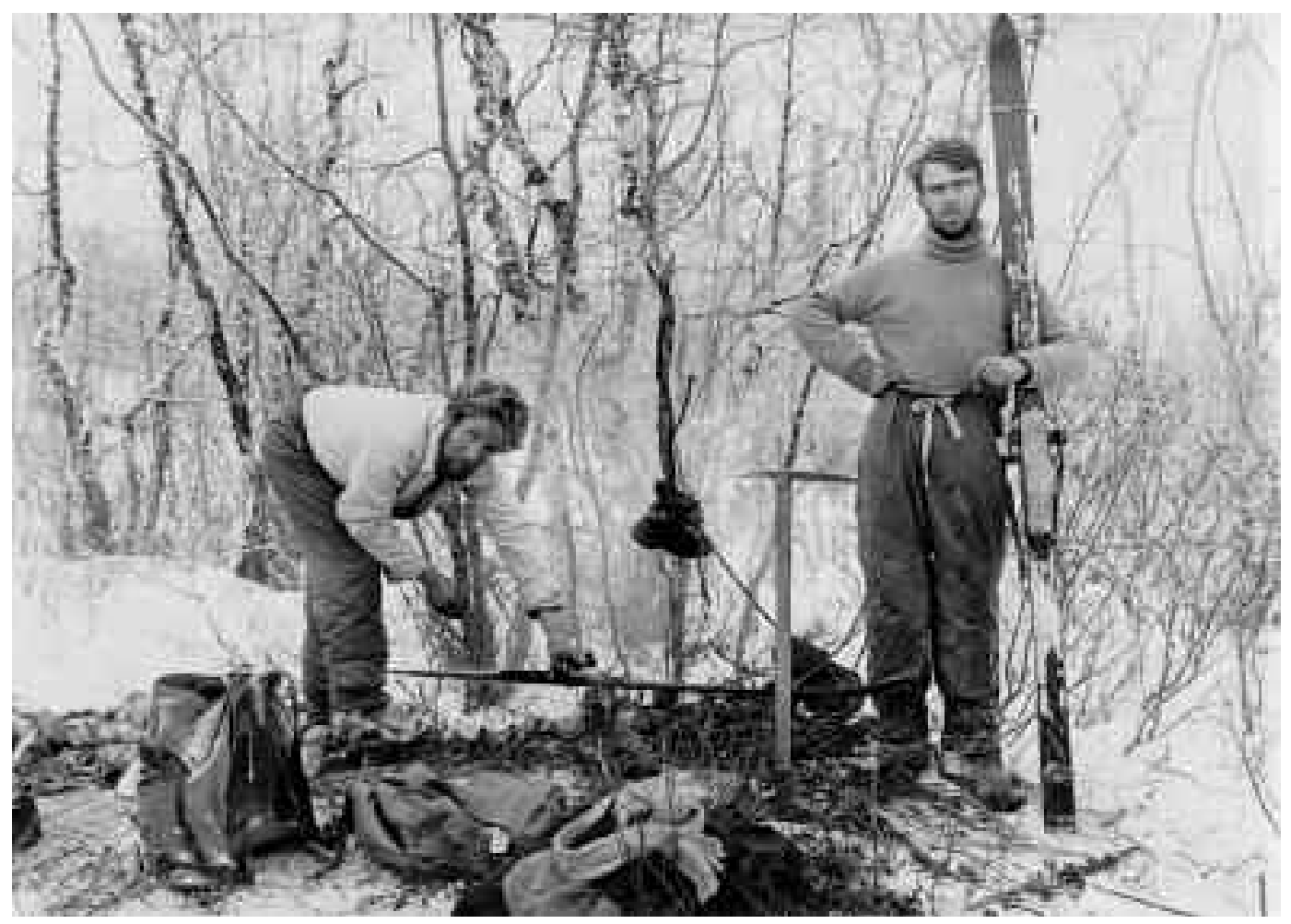

Tom Manning and Reynold Bray (1911-1936) on expedition 21 October 1932. Photograph T. Dahill of Kiruna, northern Sweden.

ing, construction and operation of an airfield and weather stations on Southampton Island. He spent the rest of the war on defence-related geodetic surveys in the north, as well as the design and development of Arctic clothing and equipment for the armed services. Tom served in the navy from 1941 to 1945 , leaving with the rank of Lieutenant Commander.

Following the war, Tom's services were sought by the Defence Research Board, the Geodetic Survey, the Geographical Branch, and other agencies of the Canadian Government. Assignments included the exploration of islands discovered in Foxe Basin by air photographs in 1948, a survey of Banks Island, an oceanographic survey in the Beaufort Sea, and many coastal surveys. Throughout his travels, Tom continued to collect specimens of birds, mammals, plants and occasionally insects. The National Museum of Canada was one of the fortunate recipients of these valuable specimens. In 1949 Tom introduced the seventeen year old Andrew Macpherson to the Arctic. They became fast friends and made several expeditions together, collaborating on many reports of their findings. These journeys, with their combined achievements in the fields of science and exploration, are well known. Accounts of
Tom's work have appeared over the last few years in newspapers and journals around the world. In these articles writers have paid extensive tribute to his work. Many of his colleagues and acquaintances noticed that Tom was as much at ease at a formal dinner as on the snow-scoured rock of the Arctic Barrens. However, he preferred the familiar landscape of the Barrens and was able to make himself comfortable in surroundings and circumstances that many civilized people could not endure.

After leaving the North, in 1941, Tom lived briefly in Montreal. Later, he and his wife bought a house in Ottawa on Linden Terrace where they entertained many of their northern friends. Tom started the Arctic Circle Club, 14 November 1947, when the guests no longer fitted around the huge oak dining-table that he had made himself. He was an expert craftsman, making cabinets for his house and building book shelves for his huge library. He and Jackie also spent hours patiently binding many of the collected volumes.

When I first met him in 1965, Tom had given up his Arctic exploration and much of his scientific work. In the tradition of his grandfather T. A. Manning (TAM), he had become a farmer, an occupation which had 
always interested him. However, Tom's grandfather in Northampton, had forsaken farming and instead, founded a brewery continued by his son TEM. The prospect of this confining tradition was one of the forces that drove Tom to some of the most remote regions on the planet. However, he made some reconciliation with his heritage about 1960 , by purchasing and working over 500 acres of hayfield, pasture and woodlot in the Merrickville countryside, some fifty km south of Ottawa. He, and his Arctic friends, built a cabin on the largest portion of property which he also used for pasture. Tom went on to renovate a stone house and rework the fertile land into a self-sustaining farm with a huge and immaculate vegetable garden, cattle, sheep, chickens and geese.

Tom and I talked a great deal about his northern trips. I finally convinced him that he should go back to his scientific work, and that I would make an excellent assistant! He cut back on the livestock and farming operations, making them manageable for summer and occasional fieldwork. Our first trip was to western Canada collecting birds, mammals and plants. We travelled in a truck, which Tom had skillfully rebuilt as a home on wheels, complete with woodstove. He said it reminded him of caravan holidays as a child, and he always took immense pleasure in its rugged simplicity - often preferring to sleep in it, even when it was parked at home.

My suggestion led to four decades of collaboration. I usually acted as assistant, and collected and prepared the birds with the hunting and skin preparation skills that Tom had taught me. There was ample opportunity for me to paint landscapes and wildlife studies on all the expeditions we made; and Tom was always encouraging and supportive of my work. Occasionally I could provide help with illustrations or maps for his scientific papers. My first trip North with him was to Cape Henrietta-Maria, tagging polar bears for the Canadian Wildlife Service, under the direction of Dr. Charles Jonkel. Although I saw no bears, I fell in love with the land and, from then on, understood and shared Tom's passion for this fabulous country. I was soon to see many bears, and we worked together from 1968 to 1973 on the Circumpolar Polar Bear Project.

During these travels, I had a firsthand chance to see Tom's unique skills. As always, he collected as many types of specimens as he could, and kept extensive field notes and descriptions of everything we encountered. Unlike many Arctic explorers of his time and previously, Tom had a broader range of interests, and documented everything he considered important. At the time, I did not fully comprehend either Tom's skills or his decision-making process. Later, through field experience, I began to understand the brilliance of his mind and abilities.

On one occasion he piloted an open boat in dense fog through seven miles (about $11 \mathrm{~km}$ ) of the unforgiving waters of James Bay, using dead reckoning and expe-

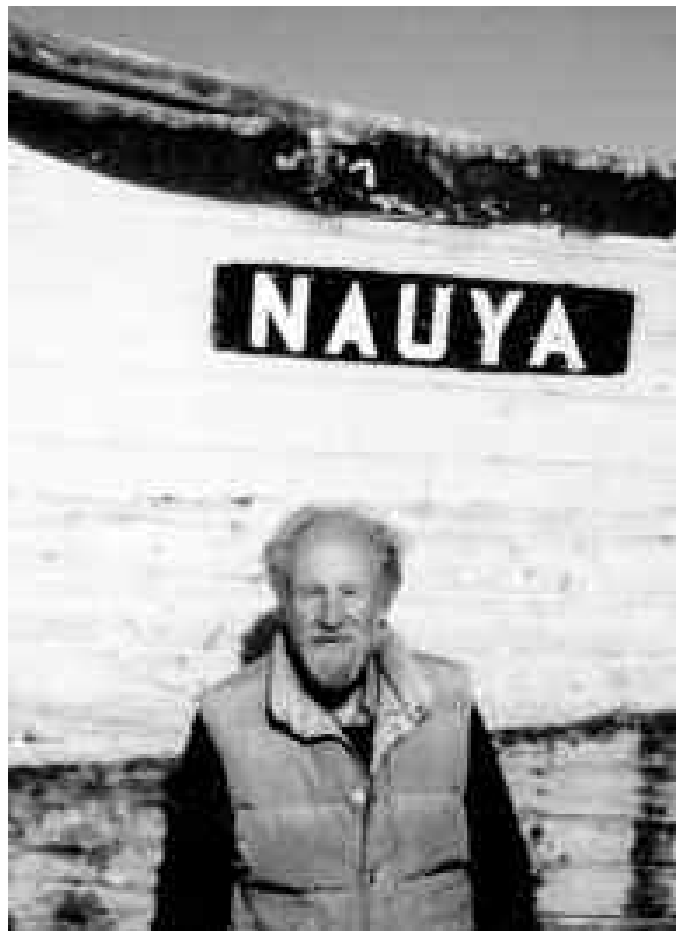

Tom with beached hull of former 1949 expedition ship Nauya behind him, Igloolik, 1983, Photograph by Brenda Carter.

rience to arrive at South Twin Island, exactly on target. On another occasion, attempting an open water crossing on the Belcher Islands, we ran into a dangerous pack-ice jam. This hazard was further compounded by an early snowstorm and a five-foot $(1.5 \mathrm{~m})$ tide rip. To stay meant being stranded. To leave meant facing rough water in an overloaded canoe. Tom's choice literally meant life or death. As usual, he made the right decision - elegant in its simple, straightforward truth. Despite the blinding snow he found a path through the heavy waves and got us safely ashore. He always kept part of his mind tuned to the essential core of any situation, a trait which was the quiet binding of his life.

From 1975 to 1986, Tom continued his collecting trips by truck in the summer, spending winters writing papers (a task he disliked) interspersed with his favourite seasonal activities of gardening, cutting fence-posts and filling the woodshed from his hardwood bush. Renewing his interest in his boyhood pursuit of eggs, he began to locate and weigh the eggs of different species. He could often be seen in nearby swamps with his odd, long-legged wooden table, a set of scales and an umbrella to shade the eggs. We both enjoyed the nest hunting and Tom became very interested in the results of his weight loss experiments, but the statistics proved daunting. I often wonder if a modern comput- 
er would have helped him with his puzzles. However, his resulting papers were successful, and the most requested from scientists around the world.

In 1983 Tom and I made our last trip north together. As we left Iqaluit for Igloolik, we had a poignant exchange. Looking down at the shorelines and islands that Tom had explored and mapped as a young man, I said that I thought I had come into his life fifteen years too late, and asked him what he felt as he looked down. He said that he thought he also had arrived in the North fifteen years too late! At the age of seventy-five, he continued to dream of an unmapped place and an era when the Arctic was truly beyond the reach of ordinary travel.

On that trip, I noticed that Tom was walking badly; and for the first time since I met him, I realized that I was able to outwalk him. This was startling and worrying and we soon learned that he had Parkinson's disease. However, he continued to work with great energy on the farm. When Parkinson's disease forced him to give up his Arctic work, Tom donated his extensive collection of rare Arctic books along with his field journals and papers to the newly formed library in Iqaluit. He also made a very generous gift of one million dollars to the University of Cambridge towards their new library at the Scott Polar Research Institute. He is remembered there in a special room, the "Manning Archives".

Then, following a broken hip, Tom had to have an operation. This trauma caused the Parkinson's disease to accelerate. After 10 years of his usual bravery and independence, Tom became extremely ill. However, he exhibited the same stoic patience that he had while waiting out a blizzard. One of his last projects was to slowly dig two new flower beds. His dry humour never vanished, but the struggle became very difficult. In November of 1998, at the age of 86 he died. He was in hospital in Smiths Falls near his home, and remarkably at peace. He left many legacies behind, including a gift of $\$ 100000$ to the Ottawa Field Naturalist Club. The council decided that $80 \%$ of interest from this bequest would go to assist authors with publication charges for the Canadian Field-Naturalist, primarily for northern papers.

Tom was a renowned Arctic explorer and zoologist whose life was characterized by a love of adventure, self-reliance, and an ever-inquiring mind. In fact as Graham Rowley describes in his wonderful book, Cold Comfort: My Love Affair with the Arctic, (McGillQueen's University Press, 1996) what Tom accomplished will never be equalled. He was also a wonderful companion and brilliant teacher, showing by example how to use intuition and logic to unravel a crisis and how to see both facts and beauty in the natural world. He was quiet to the point of being taciturn, and slow to join in the mindless customs of society. But, his loyalty to his friends and to his family in England was complete. Those who were privileged to know him well miss him in many, many ways.
Other tributes to Tom have appeared in several newspaper articles as well as an obituary in Arctic 52 (1): 104-105 [March 1999] by Andrew H. Macpherson. Tributes to his disciple Andrew Hall Macpherson (19322002) and Manning's role as his mentor have appeared in The Daily Telegraph (London, England) 22 June 2002 and in Arctic 55(4): 403-406 (December 2002) by Frank L. Miller.

\section{Awards}

1944 - Bruce Medal of the Scottish Geographical Society and the Philosophical Society of Edinburgh.

1948 - Patron's Medal of the Royal Geographical Society

1959 - Guggenheim Fellowship held for Arctic research

1974 - Officer of the Order of Canada

1977 - Massey Medal of the Royal Canadian Geographical Society

1977 - Queen's Jubilee Award

1979 - Honorary LLD from McMaster University

1992 - Doris Huestis Speirs Award in recognition of his pioneering work on birds in the Canadian North

Positions in Scientific and Professional Societies

Fellow: Royal Geographical Society; Royal Canadian Geographical Society (also a term as Director) Arctic Institute of North America (also Executive Director 1955-1956).

Member: American Ornithological Union; Wilson Ornithological Club; Cooper Ornithological Club; Wildlife Society; American Society of Mammalogists; Society for American Archaeology. Founder: Arctic Circle Club; 1947 (also Secretary 1948-1950)

Research Associate: Canadian Museum of Nature (1970-1990)

\section{Bibliography}

\section{Publications}

Manning, T. H. 1936. Some notes on Southampton Island. Geographical Journal 88: 232-242.

Manning, T. H. 1942. Remarks on the physiography, Eskimo and mammals of Southampton Island. Canadian Geographical Journal 25: 17-35.

Manning, T. H. 1942. Notes on some fish of the eastern Canadian Arctic. Canadian Field-Naturalist 56: 128-129.

Manning, T. H. 1942. Blue and Lesser Snow geese on Southampton and Baffin Islands. Auk 59: 158-175.

Manning, T. H. 1943. Notes on the coastal district of the eastern barren grounds and Melville Peninsula from Igloolik to Caper Fullerton. Canadian Geographical Journal 26: 84-105.

Manning, T. H. 1943. The Foxe Basin coasts of Baffin Island. Geographical Journal 101(5, 6): 225-251.

Manning, T. H. 1943. Notes on the mammals of south and central west Baffin Island. Journal of Mammalogy 24: 47-59.

Manning, T. H. 1943. Notes on the birds of Southampton Island, Baffin Island and Melville Peninsula. Auk 60: 504536. [prepared partially from the notes of R. J. O. Bray, who died on the expedition]

Manning, T. H. 1944. Hunting implements and methods of the present day Eskimos of north-west Hudson Bay, Melville Peninsula, and south-west Baffin Island. Geographical Journal 103: 137-152.

Manning, T. H., and E. W. Manning. 1944. The preparation of skins and clothing in the eastern Canadian Arctic. Polar Record 28: 156-169. 
Manning, T. H. 1944. Lesser Snow and Blue Geese on Southampton Island. Auk 61: 146-147.

Manning, T. H. 1946. Ruins of Eskimo stone houses on the east side of Hudson Bay. American Antiquity 11(3) 201202.

Manning, T. H. 1946. Bird and mammal notes from the east side of Hudson Bay. Canadian Field-Naturalist 60: 71-85.

Manning, T. H. 1947. Explorations on the east coast of Hudson Bay. Geographical Journal 109: 58-75.

Manning, T. H. 1948. Eskimo stone house ruins on the east side of Hudson Bay: A correction. American Antiquity 13 (3).

Manning, T. H. 1948. Pipestems of the Caribou Eskimos. American Anthropologist 50: 162-163.

Manning, T. H. 1948. Notes on the country, birds and mammals west of Hudson Bay between Reindeer and Baker lakes. Canadian Field-Naturalist 62: 1-28.

Manning, T. H. 1949. The birds of northwestern Ungava. Pages 155-224 in A Summer on Hudson Bay by Mrs. T. H. Manning. Hodden and Stoughton Ltd.

Manning, T. H. 1949. The varying lemming in captivity in Ottawa. Arctic Circular 3: 20-21.

Manning, T. H. 1950. Tidal observations in Arctic waters: Notes on the tides along the south Hudson Bay and west James Bay coasts. Arctic 3: 95-100.

Manning, T H. 1950. Eskimo stone houses in Foxe Basin. Arctic 3: 108-112.

Manning, T. H. 1950. A mixed Cape Dorset-Thule site on Smith Island, east Hudson Bay. Annual Report of the National Museum of Canada 1949-50, Bulletin 123: 64-71.

Manning, T. H., et al. 1950. The voyage of C. G. M. V. Nauja to Foxe Basin in 1949. 158 pages, plus maps, photographs.

Manning, T. H. 1951. Remarks on the tides and driftwood strand lines along the east coast of James Bay. Arctic 4: 122-130.

Manning, T. H. 1952. Birds of the west James Bay and southern Hudson Bay coasts. National Museum of Canada Bulletin 125: 1-114.

Manning, T. H., and D. F. Coats. 1952. Notes on the birds of some James Bay islands. Annual Report of the National Museum Canada 1950-51, Bulletin 126: 195-207.

Manning, T. H., and A. H. Macpherson. 1952. Birds of the east James Bay coast between Long Point and Cape Jones. Canadian Field-Naturalist 66: 1-35.

Manning, T. H. 1953. Narrative of an unsuccessful attempt to circumnavigate Banks Island by canoe in 1952. Arctic 6: 170-197.

Manning, T. H. 1953. Notes on the fish of Banks Island. Arctic 6: 276-277.

Manning, T. H. 1954. Remarks on the reproduction, sex ratio, and life expectancy of the varying lemming, Dicrostonyx groenlandicus, in nature and captivity. Arctic 7: 36-48.

Manning, T. H. 1956. The northern red-backed mouse, Clethrionomys rutilus (Pallas), in Canada. National Museum of Canada Bulletin 144: 1-67.

Manning, T. H. 1956. Narrative of a second Defence Research Board expedition to Banks Island, with notes on the country and its history. Arctic 9(1, 2): 1-77.

Manning, T. H., E. Q. Hohn, and A. H. Macpherson. 1956. The birds of Banks Island. National Museum of Canada Bulletin 143: 1-144.

Manning, T. H., and A. H. Macpherson. 1958. The mammals of Banks Island. Arctic Institute of North America Technical Paper 2: 1 -74.
Macpherson, A. H., and T. H. Manning. 1959. The birds and mammals of Adelaide Peninsula, N.W.T. National Museum of Canada Bulletin 161: 1-63.

Manning, T. H. 1960. The relationship of the Peary and barren ground caribou. Arctic Institute of North America Technical Paper 4: 1-52.

Manning, T. H. 1961. Comments on "Carnivorous Walrus and Some Arctic Zoonoses". Arctic 14(1): 76-77.

Manning, T. H., and A. H. Macpherson. 1961. A biological investigation of Prince of Wales Island, N.W.T. Transactions of the Royal Canadian Institute 33: 116-239.

Macpherson, A. H., and T. H. Manning 1961. Pack dogs in the Canadian Arctic. Polar Record 10: 509.

Manning, T. H. 1964. Age determination in the polar bear, Ursus maritimus Phipps. Canadian Wildlife Service Occasional Paper 5: 1-12.

Manning, T. H. 1964 Geographical and Sexual Variation in the Long-tailed Jaeger, Stercorarius longicaudus Vieillot. Biological Papers of the University of Alaska. (7): 1-16.

Manning, T. H. 1969 Wreckage on Banks Island. Beaver Autumn: 21.

Manning, T. H. 1971. Geographical variation in the polar bear Ursus maritimus Phipps. Canadian Wildlife Service Report Series 13: 1-26.

Manning ,T. H. 1974. Variations in the skull of the bearded seal. Biological Papers of the University of Alaska (16).

Manning, T. H. 1976. Birds and mammals of the Belcher, Sleeper, Ottawa and King George islands, Northwest Territories. Canadian Wildlife Service Occasional Papers 28: $1-42$, maps, tables.

Morrison, R. I. G., T. H. Manning, and J. A. Hager. 1976. Breeding of the Marbled Godwit, Limosa Fedoa, in James Bay. Canadian Field-Naturalist 90: 487-490.

Morrison, R. I. G., and T. H. Manning 1976. First breeding records of Wilson's Phalarope for James Bay, Ontario. Auk 93(3): 656-657.

Manning, T. H., and B. Carter. 1977. Incidence of runt eggs in the Canada Goose and Semipalmated Sandpiper. Wilson Bulletin 89: 469.

Manning, T. H. 1978. Measurements and weights of eggs of the Canada Goose, Branta canadensis, analyzed and compared with those of other species. Canadian Journal of Zoology 56: 676-687.

Manning, T. H. 1979. Density and volume corrections of eggs of seven passerine birds. Auk 96: 207-211.

Manning, T. H. 1981. Analysis of weight lost by eggs of eleven species of birds during incubation. Canadian FieldNaturalist 95: 63-68.

Manning, T. H. 1981 Birds of the Twin Islands, James Bay, N.W.T., Canada. National Museum of Natural Sciences, Syllogeus 30: 1-50.

Manning, T. H. 1982. Daily Measurements of Variation in weight loss of eggs of seven Passerine Species before and during natural incubation. National Research Council of Canada 60: 3143-3149.

Barker, A. J., J. L. Eger, R. L. Peterson, and T. H. Manning. 1983. Geographic variations and taxonomy of Arctic Hares. Acta Zoologica Fennica 174: 45-48.

\section{Unpublished Reports}

Manning, T. H. 1944. Descriptive report to the Geodetic Service of Canada on a survey of the east Hudson Bay coast. 64 pages plus maps, photographs. 
Manning, T. H. 1945. Report on Exercise Lemming to the Geodetic Service of Canada. 21 pages plus 4 pages, plus photographs.

Manning, T. H. 1945. Descriptive report to the Geodetic Service of Canada on a survey of northern Manitoba and southeast Keewatin. 54 pages, plus photographs.

Manning, T. H. 1945. Technical report to the Geodetic Service of Canada on a survey of northern Manitoba and southeast Keewatin. 179 pages, plus maps, photographs.

Manning, T. H. 1946. Report to the Geodetic Service of Canada on Exercise Muskox and on the Cambridge Bay observation station. 25 pages, plus photographs.

Manning, T. H. 1946. Descriptive report to the Geodetic Service of Canada on a survey of Ungava, east Hudson Bay, and the south coast of Hudson Strait. 133 plus 49 pages, photographs and maps.

Manning, T. H. 1946. Technical report to the Geodetic Service of Canada on a survey of Ungava, east Hudson Bay, and the south coast of Hudson Strait. 90 pages, maps.

Manning, T. H. 1947. Preliminary report on a background study of the caribou, Rangifer caribou caribou (Gmelin) and Rangifer arcticus caboti Allen of the Labrador Peninsula and the Province of Quebec north of the St. Lawrence. (Mimeo).

Manning, T. H. 1947. Descriptive report to the Geodetic Service of Canada on a survey of the west James Bay and southern Hudson Bay coasts. 166 pages, plus maps, photographs.

Manning, T. H. 1947. Technical report to the Geodetic Service of Canada on a survey of the west James Bay and southern Hudson Bay coasts. 64 pages, plus maps.

Manning, T. H. 1948-49. Reports to Defence Research Board. 1. South coast of Hudson Bay, 147 pages, plus photographs, maps, charts, etc. II. West side of James Bay, 185 pages, plus photographs, etc. FV. East coast of James Bay, 295 pages, plus photographs, etc.

\section{Professional Experience}

1931 (summer) - Traveled in Iceland and Faro Islands.

1932-33 (winter) - Traveled through Norway, Sweden, Finland, and Russia (Bergen to Murmansk) on foot and with reindeer.

1933-35 - Mapped Southampton Island and also studied and made collections of birds and mammals.

1936-41 - Leader, surveyor and ornithologist on the British Canadian - Arctic Expedition, working in Southampton and Baffin islands and Repulse Bay areas: included two years in Foxe Basin which was circumnavigated by whale boat.

1941-45 - Royal Canadian Navy. Seconded as an advisor to the U.S. Army in connection with the sighting and construction of the air field and establishment by tractor train of outlying weather stations on Southampton Island; and later to the Geodetic Service (Canada) to fix ground controls for air photographic survey of northern Canada (until 1947).

1944 - Geodetic work in Ungava by aircraft and Peterhead boat.

1945 - Geodetic work in west Hudson Bay by aircraft.

1946 - Geodetic work in Ungava, east Hudson Bay and west Hudson Strait by aircraft and Peterhead boat.

1947 - Geodetic work by canoe along the west James Bay and southern Hudson Bay coasts.
1948 - Consultant to Defence Research Board.

1949 - Leader, Geographical Bureau's expedition in C. G. M. V. Nauja to "new" islands in Foxe Basin: included circumnavigation of Foxe Basin. Soundings and tidal observations taken.

1950 - Canoe journey to collect birds and mammals along east James Bay.

1951 - Leader, Defence Research Board expedition to the Beaufort Sea and Master C.G.M.V Cancolim (included "circumnavigation" of Alaska). About 4000 miles of soundings taken.

1952 - Leader, Defence Research Board expedition to Banks Island: included attempted circumnavigation of the Island by canoe.

1953 - Completion of circumnavigation of Banks Island.

1954 - Worked up results of Banks Island Expedition under contract with Defence Research Board, and others.

1960 (June to July) - West Coast of North America with Diana Rowley

1967 - Introduction of caribou from Coats Island to Southampton Island for Canadian Wildlife Service.

1968 (June 14 - August) - Western Canada collecting by truck assisted by Brenda and Charlotte Carter; (September) - Cape Henrietta-Maria with Brenda Carter, Dick Russell and Chuck Jonkel for Canadian Wildlife Service.

1969 - Alaska collecting by truck assisted by Z. E. Ellshoff

1970 (July 21 - August) - South Twin Islands, polar bear trapping with Brenda Carter for Canadian Wildlife Service.

1971 (May 2 - September) - Belcher Islands, Sleeper Islands and Ottawa Islands with Brenda Carter for Canadian Wildlife Service.

1972 (May - June) - UK and Norway measuring bear skulls with Charlotte Carter; (September 10 - October 18) -North Twin Island, polar bear trapping with Brenda Carter for Canadian Wildlife Service.

1973 (March 22 - April 17) - Fort George and Belcher Islands, helicopter polar bear tagging with Brenda Carter for Canadian Wildlife Service; (May 2 - August 1) - North Twin Island, polar bear work with Brenda Carter for Canadian Wildlife Service; (August 13 - September 12) - Foxe Basin helicopter work with Brenda Carter for Canadian Wildlife Service.

1975 (May 15 - July 16) - Collecting at North Point, James Bay.

1977 - Yukon collecting by truck and making a floral and faunal inventory of the Dempster Highway assisted by Jan Rowell and Wendy Earl (who departed Dawson City). Robert Porsild and his wife were visited.

1980 - New Brunswick collecting by truck.

1982 - Manitoulin Island collecting by truck assisted by Doug Perkins

1983 - Igloolic Wildlife description. Advisor to adult Inuit for Igloolic Education Council.

1983 - USA (Mississippi, Louisiana, Nevada, Utah and Texas) collecting by truck assited by S. C. Tuutz.

1986 - Yukon collecting by truck (age 77) assisted by Bridget Ryan.

Most of the specimens collected on these trips were sold either to the National Museums of Canada or Carleton University. 